\title{
Do governments delay the implementation of parliamentary requests? Examining time variation in implementing legislative requests in Switzerland
}

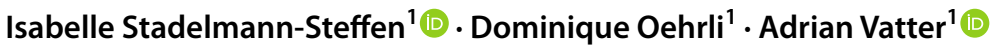

Accepted: 5 May 2021 / Published online: 13 July 2021

(C) The Author(s) 2021

\begin{abstract}
This paper investigates time variations in the implementation of legislative requests by the Swiss government. Combining the literature on executive-legislative relations with findings from implementation research, we focus on the procedural level and argue that implementation delays can occur because the government does not want to, cannot or should not implement faster. We test these mechanisms using a unique database, which enables us to analyse a systematic collection of all legislative requests that have been approved between the parliament's 2003 winter session and its 2018 spring session. Our results show that the considerable variation in the time needed for the legislative mandates' implementation is mostly related to the Swiss government's inability to transpose faster, i.e. to factors like highly busy administrative offices or complex and controversial issues. In contrast, there is no support for the ideas that the government "shall not" or "does not want to" transpose faster.
\end{abstract}

Keywords Parliamentary requests $\cdot$ Motions $\cdot$ Implementation delay $\cdot$ Executive-legislative relation $\cdot$ Rule-making $\cdot$ Implementation $\cdot$ Switzerland

\section{Introduction}

Legislation is one of parliaments' core functions. The legislature's active influence on the legislative process primarily depends on the degree of institutional independence between government and parliament (Colomer \& Negretto, 2005; Shugart \& Carey, 1992). In contrast to parliamentary systems with a strong entanglement of powers, systems with a strong separation of powers have legislatures with an active and independent position. How the government deals with parliamentary requests, especially in these systems, and what factors influence the government's responsiveness are questions of particular democratictheoretical and practical interest, since parliamentary instruments are used as a means of both legislating and monitoring the executive. Thus, parliamentary requests are central

Isabelle Stadelmann-Steffen

isabelle.stadelmann@ipw.unibe.ch

1 University of Berne, Berne, Switzerland 
instruments that parliaments use to fulfil their legislative and control functions (Mattson, 1995). However, arguably, governments increasingly dominate this relationship and only implement parliamentary requests if they want to (Graf, 2014: 829). In parliamentary systems specifically, there is a broad scholarly consensus that the government controls the agenda, while the parliament's role is limited to accepting or rejecting proposals (Tsebelis, 2009). Nevertheless, the reality seems to be more complex even in presidential systems where, according to Tsebelis (1995: 325), "the legislature makes the proposals and the executive (the president) signs or vetoes them". Thus, the parliaments' legislative agendasetting power has usually and very generally been considered to be rather weak, which, in turn, nourishes and consolidates the "decline of parliament" thesis.

This paper, which aims at contributing to the literature on parliaments' legislative agenda-setting and control powers and the associated executive-legislative relations, takes this as its starting point. However, unlike previous research that mostly focuses on institutional factors to distinguish between strong and weak governments and parliaments (see, for example, Bernauer \& Vatter, 2019; Döring 2001; Fish, 2006; Mattson, 1995; Rasch \& Tsebelis, 2011; Siaroff, 2003), this paper emphasizes the relevance of the procedural level. We argue that in order to assess the relative power of the executive and the legislative bodies, we should go beyond formal rules and settings and consider specifically whether and to what degree the executive is able to control the legislation process in practice. One central moment is when the government reacts to parliamentary requests and implements them. Thus, our paper investigates different mechanisms explaining lengthy or speedy implementation processes. More precisely, we seek to explain time variation in implementing parliamentary requests.

We combine the literature on executive-legislative relations with findings from research on implementation and, specifically, on bureaucratic rule-making in the USA, to deduce different hypotheses about why governments do not implement parliamentary requests in due time. These mechanisms are related to procedural, rather than to institutional factors, namely: opposition from within the government (i.e. the government does not want to implement), inability to implement (i.e. the government cannot do so), or opposition from within the parliament (i.e. the government should not implement). In view of these three mechanisms, we also argue that neglecting to implement may not necessarily be an indicator of a strong government (i.e. an executive that only implements parliamentary demands if it wants to). Rather, different reasons may lead to this outcome. Hence, insights into the factors that explain the time variation in implementing parliamentary requests improve our understanding of the relationship between the executive and the legislative.

Empirically, we focus on the Swiss case and provide new insights into the factors that determine how and, particularly, how fast the government reacts to parliamentary (procedural) requests. Our central variable of interest is implementation time defined as the time between the moment the parliament approves a parliamentary request (and thus mandates the Federal Council to deal with that request) and the moment the parliament abandons it (i.e. considers the request fulfilled). We rely on official data (CUBE data set, Parliamentary Control of the Administration, 2018) that enables us to analyse the full sample of 2233 motions and postulates approved between the parliament's 2003 winter session and its 2018 spring session. The focus on many requests within a single country is well in keeping with our interest in procedural factors and allows us to keep the institutional setting constant.

The contribution of our study is twofold:

On the one hand, it provides new insights into the Swiss case, which is particularly interesting for analysing the relative power of the parliament and the government in the legislative policy-making process. Switzerland stands out for its unusual system of 
executive-legislative relations, which combines elements from both parliamentary and presidential systems (Schwarz et al., 2011; Vatter \& Wirz, 2015). Just like in presidential systems, the Swiss parliament, i.e. the Federal Assembly, enjoys a relatively independent position vis-à-vis the government (Graf et al., 2014), i.e. the Federal Council. This is because members of the government are not allowed to hold seats in the parliament (Lüthi, 2007) and the government cannot be dissolved through a vote of no confidence (Vatter, 2020). Moreover, the Swiss political system grants parliamentarians the right to initiate legislation without imposing numerical, temporal, technical, or content-related restrictions (Flick Witzig \& Bernauer, 2018; Mattson, 1995; Siaroff, 2003; Vatter, 2020). Thus, compared to their counterparts in other countries, Swiss parliamentarians are hardly constrained in their right to initiate a legislative process. However, if a Swiss member of parliament (MP) exercises his/her right to initiate legislation in Switzerland, this does not automatically curtail the executive's potential to influence the legislative outcome. Rather, legislative rules concerning parliamentary requests open different windows of opportunity for governments to influence the following legislative process. Indeed, the Swiss government has repeatedly been accused of exerting its influence by delaying parliamentary requests (see, for example, Graf, 1991; Political Institutions Committee (PIC-N), 2007). Nevertheless, even though the Swiss government plays a pivotal role in shaping executive-legislative relations and, consequently, in shaping and maintaining democracy, to date, we still know little about whether and why the Swiss government really delays the implementation of parliamentary requests. This paper aims at filling this gap theoretically and empirically.

On the other hand, the present study and its results are also relevant beyond the Swiss case. First, it departs from the fact that in parliamentary systems, legislatures tend to be considered particularly weak. While in theory, "the legislature notionally controls the executive, the relationship often in practice works the other way around" (Russel and Cowley, 2016: 121). Accordingly, in many parliamentary systems the government effectively initiates legislation, while the legislature merely agrees to the executive's legislative initiatives. Thus, different studies emphasize the "parliamentary decline thesis" and, in particular, the powerlessness of the legislature in the Westminster systems (King \& Crewe, 2013; Kreppel, 2014). Knill and Tosun (2012: 139) sum up existing research: "Despite the name "parliamentary democracy', the parliament plays only a limited role in decision-making in the British Westminster model". Our article aims to provide an answer to the relevant question of what could happen if the legislature actually exercised its right to initiate legislation in practice. Using Switzerland as a test case enables us to examine the relationship between the executive and the legislative branches in a context of multipartism, coalition government, and heterogeneous cultures, which is typical of most European countries. Such analyses make it possible to draw conclusions about European countries looking for alternatives to the prevailing parliamentary system with weak legislatures, which has come under increasing criticism (see Sciarini et al., 2021).

Second, we focus on the mechanisms explaining governments' "behaviour" when they implement parliamentary requests. We expect that these mechanisms may also be relevant to other situations in which governments and their administrations implement legislative decisions. Some examples are bureaucratic rule-making (Bolton et al., 2016; Potter, 2017) and also subnational or supranational multilevel governance, e.g. the implementation of EU directives (Borghetto \& Franchino, 2010; König \& Luetgert, 2009). While both the political systems and the stages of policy making of these examples vary, all of them are characterized by an implementing body that has more or less leeway and, relatedly, power in the implementation process. The Swiss case may be particularly informative to the 
investigation of the mechanisms that shape these relationships because it is an intermediary case on the parliamentary strength continuum, incorporating both parliamentary and presidential features (Sciarini et al., 2021). ${ }^{1}$

The remainder of the paper is organized as follows: The next section seeks to contextualize our case by taking a closer look at the main instruments that the Swiss parliament can use to initiate a legislative process. In "Reasons for Delaying Parliamentary Legislative Requests: Theoretical Approach and Hypotheses" section, we discuss the main theoretical assumptions about how and why the government may delay parliamentary requests. Given the scarcity of scientific attention to these questions, we develop our theoretical framework by combining discourses and evidence from parliamentary research with key findings from implementation research and then advance our main hypotheses. The "Methodology" section focuses on our methodological approach and the operationalization of our variables. We present and discuss the findings of our statistical analysis in the "Empirical Results" section. The paper concludes with a brief summary of our main findings and a discussion of their implications.

\section{The legislative agenda-setting power of the Swiss parliament: instruments and processes}

From an international perspective, the Swiss political system stands out for its institutionalization of direct democratic instruments, its decentralized federalism, and its unique system of proportional power-sharing within and between the executive and the legislative body (Linder, 2007; Linder \& Mueller, 2021). According to these institutional features of powersharing, many different political actors, including the government and the parliament but also the people and the cantons, can provide the impetus for legislative regulations in Switzerland. While all these actors have been using their right to initiate legislation, to date, the large majority of bills is initiated and drafted by the government, i.e. the Federal Council (Vatter, 2018). Indeed, as Lüthi $(2007,140)$ puts it, the Swiss parliament's involvement in the political decision-making process often occurs at a relatively late stage. Accordingly, the parliament's legislative agenda-setting power has usually been considered to be rather weak (see, for example, Brüschweiler \& Vatter, 2018; Lüthi, 2007; Schwarz et al., 2011; Vatter, 2020). However, more recent studies indicate that MPs have increasingly been making use of instruments that allow them to set the legislative agenda themselves (see, for example, Brüschweiler \& Vatter, 2018; Jaquet et al., 2019), i.e. to use their positive agenda-setting power (Jenkins et al., 2016).

\footnotetext{
1 The Swiss parliament is an intermediary case because, on the one hand, it has a very independent and strong institutional position vis-à-vis the government (election of the government and the judiciary by the legislature, extended rights of initiative and participation, no control by a constitutional court) and on the other, the Swiss militia parliament has very few human, financial, and material resources, which significantly weakens its control and legislative power vis-à-vis the government (Vatter 2018: 58). "Focusing on the legislative agenda setting and decision-making powers, the Swiss parliament enjoys many institutional advantages and thus is very strong indeed. However, focusing on the whole policy-making process, including the pre- and post-parliamentary stage, the strong position of the parliament disappears and the government turns out to be the most influential political actor due to its positional advantages" (Schwarz et al. 2011: 141). In short, the Swiss parliament is formally strong but informally weak.
} 
To do so, MPs have different instruments at their disposal. ${ }^{2}$ We focus on the two instruments that oblige the government (i.e. in a binding way) to get active and implement the parliament's requests. The so-called motions are the first such instrument. Through a motion, the parliament forces the government to submit a bill to the parliament and/or to take a certain action (Article 120(1) ParlA). ${ }^{3}$ Postulates are a second, weaker instrument at parliamentarians' disposal. Postulates mandate the Federal Council to examine and report whether a bill and/or another measure should or should not be introduced.

Motions' and postulates' process requirements are generally the same, with some exceptions: Both types of parliamentary requests can be submitted by a parliamentarian committee, but they can also be presented by a single council member or a parliamentary group. While a motion is only issued and transferred to the Federal Council if approved by both chambers of the parliament, postulates only need to be approved by the parliament chamber in which they have been submitted. It should be noted that in many cases, parliamentary requests are tacitly approvedthe parliament does not explicitly vote on them. In fact, an explicit vote is only held if an item of business is opposed by at least one member of the National Council, i.e. the lower chamber, or by the government which, for its part, issues its acceptance or rejection in the run-up to the parliament's decision. Additionally, a vote may be held if a proposal has been submitted by a parliamentary committee and a minority of this parliamentary committee opposes its approval.

Once the parliament approves the motion, the government implements it and, if it is fulfilled, requests its abandonment. ${ }^{4}$ The parliament then votes on the request. The abandonment of a postulate only requires the consent of one chamber-the chamber that has approved it-while motions need to be abandoned by both chambers (Article 124(5) ParlA). With motions, "[i]f a request for abandonment is rejected by both chambers, the government must fulfil the request contained in the motion within one year or within the period fixed by the two chambers on rejecting the request" (Article 122(5) ParlA). ${ }^{5}$

In light of our research question, it is important to note that this deadline only applies to motions for which the government has already issued an abandonment request. The Parliament Act does not, however, generally determine a formal time limit within which the government must implement a motion or a postulate after its approval. The only reference to a time limit in the Parliament Act indicates that the executive has to report on motions and postulates still pending two years after the parliament has approved them. In these reports,

\footnotetext{
2 Parliamentary initiatives that enable individual MPs, a parliamentarian group, or a parliamentarian committee to propose a draft on a new enactment are another important instrument (Swiss Parliament, 2019). We do not include it because law making is the parliament's responsibility, while the government is only involved at a late stage. Moreover, MPs can also make use of the instruments of interpellations and parliamentary questions (Bailer, 2011).

${ }^{3}$ Graf (2014: 829) mentions in that respect that the increasing number of motions in recent years has led to a situation in which the Federal Council is no longer able to really cope with these requests both in quantitative and qualitative terms. This had led to a devaluation of the motions, in practise, whereby they are often not treated as bindingly as required by law.

4 Abandonment may also be requested for unfulfilled requests which, according to the government, should not be carried out (Article 122(3) ParlA). However, these are rare cases that we do not specifically consider in this study. Indeed, based on a subsample of 600 requests, abandonment without fulfilment only occurred in 14 cases. Moreover, the Federal Council did initially support the majority of these cases and took some action towards their fulfilment. This implies that the decision to leave these items of business unfulfilled was not clear from the start.

5 If, however, the two chambers have adopted divergent decisions, a second rejection by either chamber is seen as final (Article 95 ParlA).
} 
the government has to explain what it has already done to fulfil the parliamentary request as well as any additional plans to further deal with its fulfilment.

Motions and postulates do not generally curtail the Federal Council's potential influence on the legislative process. The parliamentarian political institutions committee has advanced an important critique: that the executive influences the law-making process through motions and postulates by delaying parliamentary requests. Such implementation delays, i.e. a long period between the parliament's adoption of the request and the request's abandonment, are possible due to the lack of formal time frames for the implementation of motions and postulates. In the next section, we discuss potential theoretical grounds for this assumption.

\section{Reasons for delaying parliamentary legislative requests: theoretical approach and hypotheses}

As the introduction mentioned, the time variation in the implementation of parliamentary requests has hardly ever been empirically addressed. Accordingly, this topic also lacks theoretical foundations. However, this gap can be filled by combining the general findings of the studies on executive-legislative relations and on the institutional dimensions of the decision-making process with findings from implementation research. The latter seems to be particularly appropriate for analysing governments' executive function, which is inherently linked to bureaucratic politics.

We depart from theoretical approaches that conceptualize the dimensions and determinants of (non-)compliance with legislative directives, which have been prominent in the field of multilevel implementation research (see, for example, Börzel, 2001; Chayes \& Handler Chayes, 1993; Falkner et al., 2005; Simmons, 2002). More precisely and in accordance with Falkner et al. (2005), we understand non-implementation or delayed implementation as subforms of non-compliance, which can emanate from an (unintentional) inability to implement parliamentary requests or intentional opposition to implementation. In the latter case, opposition to implementation can emerge from within the Federal Council itself, but also from other political actors which, in turn, might restrain the Federal Council's options of accurately implementing requests. We argue that the non-implementation or the delayed implementation of parliamentary requests by the Federal Council can result from the facts that the Federal Council (a) cannot accurately implement requests (inability), (b) shall not accurately implement requests (opposition from outside the Federal Council), or (c) simply does not want to accurately implement requests (opposition from within the Federal Council). Similar mechanisms - especially the distinction between capacity-related and political reasons for implementation delays - have been proposed by studies on bureaucratic rule-making in the USA (Bolton et al., 2016; Potter, 2017). We also rely on them to specify our theoretical expectations. In what follows, we will discuss some potential determinants of delayed implementation or non-implementation resulting from these three situations more closely.

\section{Inability to implement}

Implementing parliamentary requests can be both technically challenging and resource intensive for the administrative offices in charge. The administration may sometimes just lack the capacity to implement (additional) parliamentary requests within a short time (Bolton et al., 2016; Potter, 2017). Accordingly, implementation time is a measure of administrative performance. If the administrative agencies are well equipped with personnel and resources, the implementation time should be shorter. Conversely, lengthy implementation times could be the 
result of an administrative overload at the time when requests should be implemented and, thus, a sheer inability to work faster (Bolton et al., 2016; Falkner et al., 2005; Potter, 2017).

Usually, when motions and postulates are transferred to the Federal Council, they are assigned to one of the seven ministries, i.e. government departments, or more precisely to a specific Federal Office within a government department. These assignments are contingent on the item of business's thematic focus and do not hinge on the actual workload caused by pending requests. As a result, different Federal Offices' workloads related to the implementation of parliamentary instruments vary substantially. We expect that items of business that are the responsibility of a Federal Office with a lighter workload be implemented faster than items of business that fall under the responsibility of a Federal Office with a heavy workload. Hence, we assume that implementation time is closely related to the implementation workload of the responsible office:

Hypothesis 1 The higher the workload of the responsible administrative office, the longer the government needs to implement a parliamentary request.

The specific timing of request submission may also be important for other reasons. More precisely, we expect that personnel changes within the executive add to implementation delays (for a similar argument, i.e. the "Leadership Vacancy Hypothesis", see Bolton et al., 2016). In Switzerland, members of the government are elected by the parliament for a period of four years. Upon the conclusion of these four years, incumbent councillors are either confirmed in office or (voluntarily or involuntarily) replaced. Moreover, elections are also held to replace government members who step down during their term in office (Swiss Federal Chancellery, 2019). In accordance with the executive's organizational ordinance (Article 2), the Federal Council (re-)assigns responsibilities for the seven ministries after each election. In the course of this reshuffle, ministry responsibilities can change quite substantially, especially since taking over a new ministry is not unusual among re-elected incumbents. Given that such changes entail a period of vocational adjustment, they may also cause implementation delays.

Hypothesis 2 Changing the head of the responsible ministry delays the implementation of parliamentary requests.

The capacity mechanism may also be applicable to a more content-related argument. More specifically, different types of parliamentary requests may require varying degrees of effort. However, different argumentations are plausible. On the one hand, it can be assumed that implementing motions - requests that force the executive to draft a bill-requires more time than implementing postulates which, for their part, "only" require considering the need for legislative action(s). On the other hand, there also are reasons to believe that postulates require even more time to implement, particularly if the government has to commission external experts to conduct a study and write a report. ${ }^{6}$ Given these contrasting views, we test a non-directional hypothesis ${ }^{7}$ :

\footnotetext{
6 We thank an anonymous reviewer for directing us to this possibility.

7 There are several reasons to assume that the time variation in the implementation of parliamentary requests is not only related to the type of the request itself, but also to the specific type of action required. For example, motions that only require an ordinance may be less demanding and time-consuming than motions that force the Federal Council to introduce a new bill. Yet, as further analyses (not presented here) reveal, the implementation of motions and postulates typically calls for several distinct actions. Hence, there
} 
Hypothesis 3 Motions and postulates have different implementation times.

\section{Opposition within the parliament}

The next two subsections focus on political motivations that may explain the observed variance in implementation speed. While political factors seem to be obvious in cases where we perceive the implementation of a parliamentary request as an element of the (political) executive-legislative relationship, the relevance of political motivations has also been emphasized by scholars of bureaucratic policy making (Bolton et al., 2016; Potter, 2017).

In Switzerland, the use of parliamentary requests has significantly increased over the course of the last decades (Swiss Federal Chancellery, 2019; Vatter, 2020). However, not all submitted issues of business are remitted to the executive. ${ }^{8}$ Rather, as we described in the "The Legislative Agenda-Setting Power of the Swiss Parliament: Instruments and Processes" section, to be issued and transferred to the executive, postulates need to be approved by the parliament chamber to which they were submitted. Motions even require approval by both chambers. Approval thereby suggests that the particular issue of business is supported by a majority, which does not rule out that the issue has been subject to politically controversial discussion and even to considerable opposition by a parliamentary minority. This may be especially true for items related to topics addressing traditional party cleavages and/or emotional and disputed issues more generally (see Potter, 2017, for a similar argument about a rule's impact and complexity).

In turn, opposition from within the parliament makes it more demanding for the government to implement a given item of business within a short time as such a situation obliges the administration to seek a solution accommodating as many MPs as possible. The need to elaborate convincing solutions with majority appeal does not only arise from the parliament's "blocking power" (Falkner et al., 2005). ${ }^{9}$ Comparing rule-making requests from different sources in the USA, West and Raso (2013) demonstrate that parliamentary requests take the administration longer to complete than requests initiated by other actors, not because they are assigned low priority but because they tend to involve more complex and contentious issues. On these grounds, we formulate the following two hypotheses:

Hypothesis 4 The greater the opposition to an item of business within the parliament is, the longer it takes to implement the parliamentary request.

Hypothesis 5 Long implementation periods are typical for items of business addressing topics that are politically controversial.

Footnote 7 (continued)

are multiple possible combinations, which makes it very difficult to adequately assess the potential effects of the required types of action empirically.

8 According to Brüschweiler and Vatter's (2018) data, less than $30 \%$ of all postulates and less than $20 \%$ of all motions submitted between 2004 and 2014 were actually approved and remitted to the government.

9 In Switzerland, the parliament can abandon any measure proposed by the executive in response to a parliamentary request. If this is the case, the government is obliged to resume the request and find a new solution with majority appeal. 


\section{Opposition within the government}

A main characteristic of the Swiss consensus democracy (Lijphart, 2012; Vatter et al., 2020) concerns the composition of the executive and its mode of operation (Klöti, 2007; Linder \& Mueller, 2021). A distinct feature of the Swiss government is that the executive is based on a broad coalition of seven members who proportionally represent the four largest parties. ${ }^{10}$ Consequently, the system enables different political forces to participate in government decisions and, thus, warrants shared political responsibility (Linder \& Mueller, 2021; Vatter, 2020). However, unlike conventional coalition governments, the four parties represented in the Swiss government "are not committed to a common political program" (Lüthi, 2007, 124). This implies the permanent negotiation and cooperative behaviour of the members of government (Klöti, 2007; Linder \& Mueller, 2021). This is especially so since the "principle of collegiality" is one of the most important characteristics of the Swiss Government's organizational structure. Said principle is not only contained in the provision of an equal vote for all Federal Council members, but also in Article 12 of the Government and Administration Organisation Act, which states that the Federal Council has to reach and represent its decisions as a collegial body.

The "need for partners with divergent preferences to make joint policy" (Martin \& Vanberg, 2005, 93) can be challenging. Martin and Vanberg (2005) assume that priority may therefore be given to issues that appeal to all partners in the coalition, while less appealing and more controversial issues may be more likely to be postponed. Moreover, priority for implementing a specific item of business might be rather low if the executive senses that the parliamentary request is primarily used for parliamentary oversight (Strøm et al., 2010). We therefore suggest that the assumptions about the sources and effects of opposition within the parliament stated in hypotheses 4 and 5 also hold true as far as the government is concerned. That is, requests may be given higher priority if the members of the government agree on the fact that legislative action is needed. This, in turn, implies that time variations in implementing parliamentary requests are related to the implementation preferences of the executive itself. ${ }^{11}$

Given the Federal Council's obligation to speak with one voice, we formulate the following hypothesis:

Hypothesis 6 Items of business supported by the Federal Council itself are implemented faster than items of business that the Federal Council opposes.

\section{Methodology}

We test our hypotheses empirically based on the CUBE data set (Parliamentary Control of the Administration, 2018). This database was compiled by the Parliamentary Control of the Administration (PCA), the evaluation service of the Federal Assembly. The information

\footnotetext{
10 The four parties are: Swiss People's Party, FDP.The Liberals, Christian Democratic People's Party, and Social Democratic Party.

11 This argument is in keeping with the idea that implementation delays could be a reflection of strategic calculations, a mechanism that has recently been shown to explain variation in the pace of US bureaucratic agencies' rule-making (Potter, 2017). In this view, administrations can both "fast-track" and "slow-roll" rule-making and, therefore, influence the rule's political success or failure according to their preferences.
} 
contained therein is mainly taken from the database of parliamentary proceedings, Curia Vista, ${ }^{12}$ and from the Federal Council's yearly reports on motions and postulates.

The CUBE database represents a systematic collection of all motions and postulates that were approved between the parliament's 2003 winter session and its 2018 spring session. As Table 1 shows, a total of 2233 items of business were approved during this period. About $70 \%$ of them were abandoned by the end of the 2018 spring session. The remaining parliamentary requests were still pending at that time.

Our main variable of interest (i.e. our main dependent variable) is the duration of these observations' implementation calculated as the number of days between their approval and their abandonment. As we do not know the date of abandonment of requests that are still pending, our data are right censored. We use survival analysis in order to account for this data structure and still include these most recent cases (Box-Steffensmeier \& Jones, 1997, 2004; Golub, 2007). Hence, we model implementation duration as a parliamentary request's "survival time", i.e. until it is abandoned by the parliament. A dummy variable thereby measures whether a legislative request has actually been abandoned-whether the target event has happened - or not. In a first empirical step, we present nonparametric survival curves that plot bivariate patterns of the probability that an item of business has not been abandoned after a certain duration. ${ }^{13}$ We then proceed with estimating Cox proportional hazards models that include our explanatory variables. In both empirical steps, we exclude motions and postulates (pending or abandoned) with extra-long implementation times ( $>2200$ days, $N=113$ ). This decision obeys expert assessments that such overly long implementations are not only very rare, but should also be considered outliers that often hinge on other institutional factors and peculiarities not discussed here.

Following our hypotheses, we focus on six explanatory variables. First, to measure the motion- and postulate-related workload of the responsible Federal Office's, we constructed a dummy variable which takes the value of 1 if the responsible Federal Office was in charge of at least 90 items of business during the investigated period, i.e. between the parliament's 2003 winter session and its 2018 spring session. The limit of 90 items of business is justified by empirical distribution criteria - the group of federal offices with 90 and more requests empirically stands out rather clearly from those with a (often much) smaller workload (see Fig. 5 in "Appendix"). Measuring the workload of a Federal Office is not self-evident. Yet, we argue that considering the distribution of parliamentary requests in the period under investigation and across the different Federal Offices is a simple but reliable approximation. ${ }^{14}$ There is no reason to believe that this general distribution should

\footnotetext{
${ }^{12}$ Curia Vista-Database of parliamentary proceedings, https://www.parla-ment.ch/en/ratsbetrieb/curiavista.

13 We estimate survival curves with the Kaplan-Meier method using the survfit function in R.

14 We refrain from measuring workload on a yearly or legislature basis for several reasons. The most important one is that our dataset contains parliamentary requests adopted in a specific time frame and we only have this information to calculate the workload of a Federal Office. Hence, counting the number of requests per year would lead to a biased workload measure, particularly for the first years in our sample, since requests that have been adopted earlier and are still pending would be excluded, even though they actually make up a substantial part of the "workload" of an office at that time. Moreover, parliamentary requests are typically implemented over periods longer than one year (and, eventually, even over more than a single legislature). It is not evident which year is most relevant to a speedy or lengthy implementation and whether the same point in time would be relevant to all different items of business. Neither do we control for the size of the federal office. Whether an additional parliamentary request generates a resource problem can be rather independent from the size of the federal office but more strongly contingent on the availability of the right expertise and the right people. A specific item of business will be assigned to the team within
} 
substantially vary over time. Moreover, we do not assume that the exact number of requests is related to the implementation time in a linear way but, rather, expect that there are general differences between those with many items of business to handle and their less busy counterparts. Therefore, we use a dummy specification (see Fig. 8a in "Appendix" for an alternative metric specification leading to the same result). The second explanatory variable is a dummy variable capturing whether the head of the responsible ministry changed during the implementation of the specific item of business. ${ }^{15}$ Third, in order to account for potential time variation related to the type of the parliamentary request, we use a dummy variable that differentiates between motions and postulates.

To capture opposition within the parliament, we first identified whether the parliament had voted on the approval of a specific item of business. If so, we calculated the ratio between the number of MP's voting in favour and the number of MP's voting against the item's approval by calculating the difference between the "yes" and the "no" votes and dividing it by the total number of votes. Items of business that had been tacitly approved received a value of 1 (i.e. no opposition). Thus, our opposition indicator ranges between 0 and 1 , whereby lower numbers imply a smaller majority supporting the item. In contrast, high values indicate that a broad, multiparty coalition (more or less explicitly) supported the parliamentary request.

Moreover, we want to measure an item's potential for causing political controversy, which, however, is not an easy task. Indeed, we are not able to assess the level of controversy based on a parliamentary request's content. Yet, in light of the recent political discussion in Switzerland, arguably the most heated debates usually emerge around reforms dealing with social policy provisions as well as migration-related policies. This is also reflected in the fact that those topics were most frequently subjects of optional referendums and initiatives. Given that the ministries in Switzerland are responsible for specific issue areas, we assume that ministries like the FDHA (Federal Department of Home Affairs), which is responsible for social security measures, among other things, or the FDJP (Federal Department of Justice and Police), which is responsible for (im-)migration policies, have to deal with more contested and complex issues than other ministries. ${ }^{16}$ In contrast, we expect that items that fall under the FDFA's (Federal Department of Foreign Affairs) responsibility are much less contested since the domain of foreign policies traditionally belongs to the government's exclusive realm. Accordingly, foreign policy stands outside the usual party conflicts and other domestic disputes (Goetschel, 2014; Jaquet et al., 2019). Since diplomacy is responsible for foreign policy, the parliament is more reserved in this policy area than in domestic policy and the government can be expected to implement the comparatively few parliamentary requests more quickly. Based on these assumptions, we argue that

Footnote 14 (continued)

the federal office with the greatest expertise, and the size of these teams is not necessarily larger in larger federal offices.

15 As the implementation of parliamentary requests takes some time, almost $30 \%$ of all items of business are affected by such reorganization, even though changes of department heads are generally rare (Linder and Mueller 2021; Vatter 2020).

16 An indicator of the validity of this assumption is the number of facultative referenda that fall within these ministries' jurisdictions. Facultative referendums are launched when relevant social groups oppose a parliamentary decision. This is particularly likely if the proposal was already conflictual in parliament. Considering all facultative referenda over the last 20 years shows that 27 referenda concerned social issues and 16 proposals concerned the Federal Department of Justice and Police. Conversely, only 7 facultative referendums were held on foreign affairs and 9 on public finances (www.swissvotes.ch). 
Table 1 Motions and Postulates contained in the CUBE database. Source: Prepared by the authors based on the CUBE database

\begin{tabular}{llcr}
\hline & Pending & Abandoned & Total \\
\hline Motions & 285 & 692 & 977 \\
Postulates & 384 & 872 & 1256 \\
Total & 669 & 1564 & 2233 \\
\hline
\end{tabular}

ministry responsibility may constitute a crude proxy for thematic focus and, thus, for an item's potential complexity and controversial nature. Accordingly, our analyses use dummy variables indicating the ministry that has been assigned responsibility for a particular item of business. ${ }^{17}$

Our last explanatory variable has to do with the opposition an item of business might meet with within the executive. We include a variable that measures whether the government proposed the acceptance, the partial acceptance, or the rejection of a motion or a postulate in the run-up to its approval in parliament.

Besides our crucial explanatory variables, our regression analyses control for two additional factors that may influence implementation delays. First, in order to account for potential time effects, we integrate a variable that defines the legislative term. On the one hand, this allows us to control for systematic variation in implementation time over time, namely that items that have been submitted more recently have a systematically higher probability of exhibiting short implementation times and/or not being abandoned yet. Moreover, this variable may also capture changes in the political context, namely differing political dynamics, e.g. due to varying composition of the parliament or varying degrees of polarization. Furthermore, we account for the fact that some items of business cannot be considered independent from each other. In fact, it is not unusual for MP's to join forces and individually submit a motion or a postulate with a similar or even identical content. This is done to put more emphasis on a specific topic. We control for this lack of independence by including a dummy variable that takes the value of 1 if there is an item with a similar or identical content. ${ }^{18}$

\section{Empirical results}

\section{Implementation time frames: survival curves}

Initially, we find considerable variation in the time needed for parliamentary requests' implementation. Indeed, while the government implements most parliamentary requests

\footnotetext{
17 As an alternative measure for issue complexity, we also considered a dummy identifying parliamentary requests that concern international agreements, where the multilevel nature of the decision can be seen as another source of complexity. However, this variable was not significant in the additional models presented in Fig. 8b in "Appendix" and it did not change our findings.

18 We also considered factors related to the dimension of party politics, e.g. who proposed the parliamentary request (in particular, a multiparty committee or a party) and in which chamber of the parliament was a request initiated. Theoretically, however, we argue that these factors should influence the acceptance of legislative requests, rather than their implementation. Further analyses corroborated this expectation empirically. None of these factors was significantly related to implementation times, nor did they affect the findings presented in this study. These models can be found in Fig. $8 \mathrm{~b}$ in "Appendix".
} 
within 800 to 1500 days, i.e. more or less 2 to 3 years, the implementation time of distinct, already abandoned items of business ranges between 92 days and more than eleven years (see Table 2 in "Appendix").

As shown in Fig. 1, and in contrast to our expectation (H3), this variation does not apparently hinge on the type of the parliamentary request. The figure plots the survival curves of both postulates and motions and shows that both types of parliamentary requests experience time variation in their implementation. The likelihood of being pending (which is the inverse of the probability that an item of business is abandoned) decreases as the implementation time increases. However, mean duration does not significantly vary across instruments $(p$ value $=0.91)$.

Conversely, the upper left panel in Fig. 2 shows that highly busy federal offices are characterized by significantly longer implementation times than those of their counterparts that deal with a lower number of parliamentary requests. This pattern is in accordance with our first hypothesis that implementation delays may occur due to overload. Moreover, the other plots depicted in Fig. 2 suggest that neither personnel changes, i.e. ministry reassignments within the government, nor potential opposition within either the parliament or the government significantly affect time variation in parliamentary requests' implementation. However, a closer look at the descriptive statistics presented in Fig. 6 in "Appendix" also reveals that those results need to be handled with care. In fact, the figures plotting the position of the government and the parliament suggest that opposition to parliamentary requests is the exception rather than the rule and, thus, the number of cases in these respective categories is very low. ${ }^{19}$ As far as ministry reassignments within the government are concerned, the figure (bottom left) indicates that personnel changes may increase variation in implementation time frames. Until implementation time frames reach 1800 days, changes in a ministry's leadership seem to be clearly associated with higher probabilities of non-abandonment. This pattern is reversed for very long implementation durations, which might explain the fact that the mean difference is not significant.

Lastly, Fig. 3 suggests that the responsible ministry is a relevant factor in explaining variation in parliamentary requests' implementation. What is more, Fig. 3 seems to corroborate our hypothesis that this variation is attributed to differences in the departments' thematic focus. As expected, implementation time frames seem to be particularly long for items of business that fall under the responsibility of the Federal Departments of Home Affairs and Justice and Police. Conversely, the time frames of items that fall under the jurisdictions of the Department of Foreign Affairs and the Department of Defense are particularly short.

\footnotetext{
${ }_{19}$ As far as the upper-right-side panel of the figure which focuses on the vote in parliament is concerned, it should be recalled that the Swiss parliament has to vote on the approval of any item of business that has been opposed by the executive. Accordingly, in those cases there is no need for an MP who does not agree with an item to "additionally" oppose the motion or postulate. This, in turn, implies that we cannot determine whether items that have been opposed by the government would otherwise have been opposed by the parliament or not.
} 


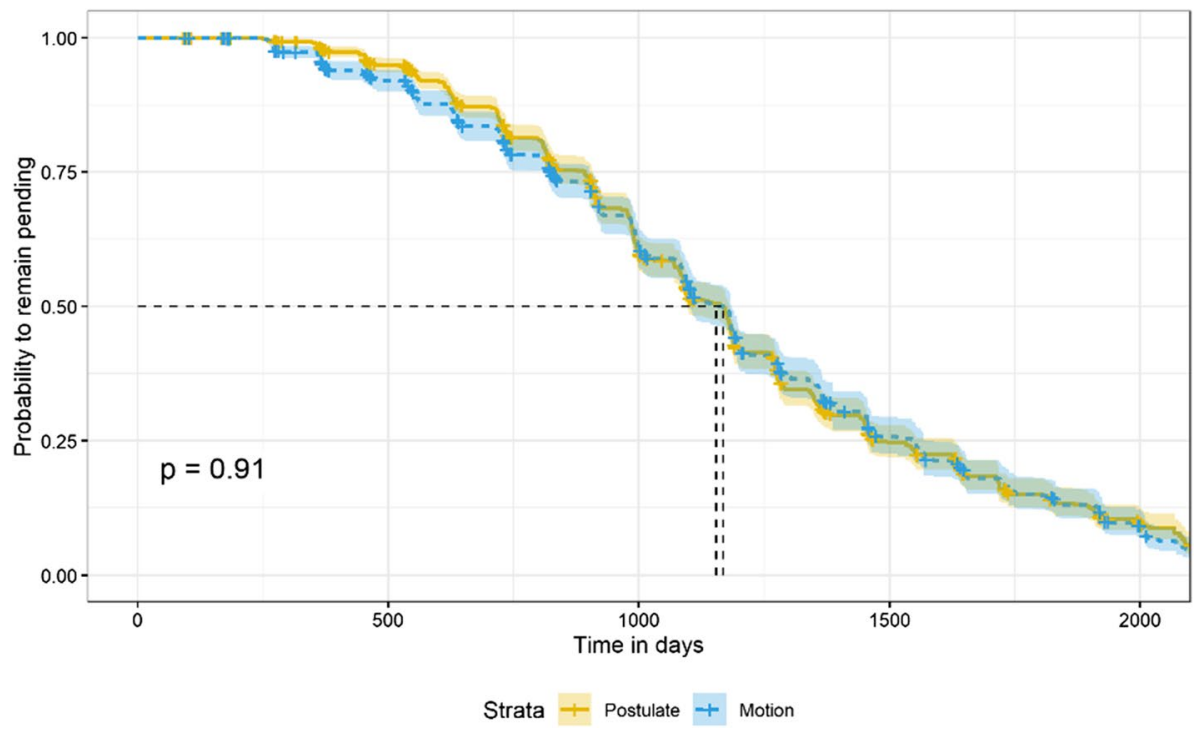

Fig. 1 Implementation time frames contingent on the request type. Note: Prepared by the authors based on the CUBE database. $N=1902$ (785 motions and 1117 postulates)

\section{Explaining time variation in implementing parliamentary requests}

To more systematically test our hypotheses, we now turn to the results of a Cox proportional hazards regression model. ${ }^{20}$ Figure 4 presents the hazard ratios (HR) based on this model and contingent on the different predictors, whereby a HR $>1$ indicates an increased likelihood of abandonment (i.e. a shorter implementation time), while a value below 1 stands for a decreased likelihood that a parliamentary request is abandoned (i.e. a longer implementation time).

The results corroborate the previous finding that implementation times do not differ between motions and postulates. ${ }^{21}$ This result probably mirrors repealing effects associated with the request's type. That is, on the one hand and as hypothesis 3 proposes, it seems reasonable to assume that implementing motions requires more time than implementing postulates, as motions force the Federal Council to fulfil the complex task of drafting a bill. On the other hand, requests are arguably ascribed greater importance than postulates which, in turn, may exert more pressure on the government to implement the request within a reasonable time.

Furthermore, the model shows that opposition within the parliament is not significantly associated with longer implementation periods.

\footnotetext{
${ }^{20}$ Further estimations using OLS regression models and focusing on abandoned legislative requests are presented in Fig. 7 in "Appendix". They largely confirm the results presented in the following discussion.

21 In additional analyses not presented here, we further investigated whether we might observe motion- or postulate-specific features when including interactions between our motion variable and the other independent variables in our model. However, we did not find any significant and substantial effects.
} 

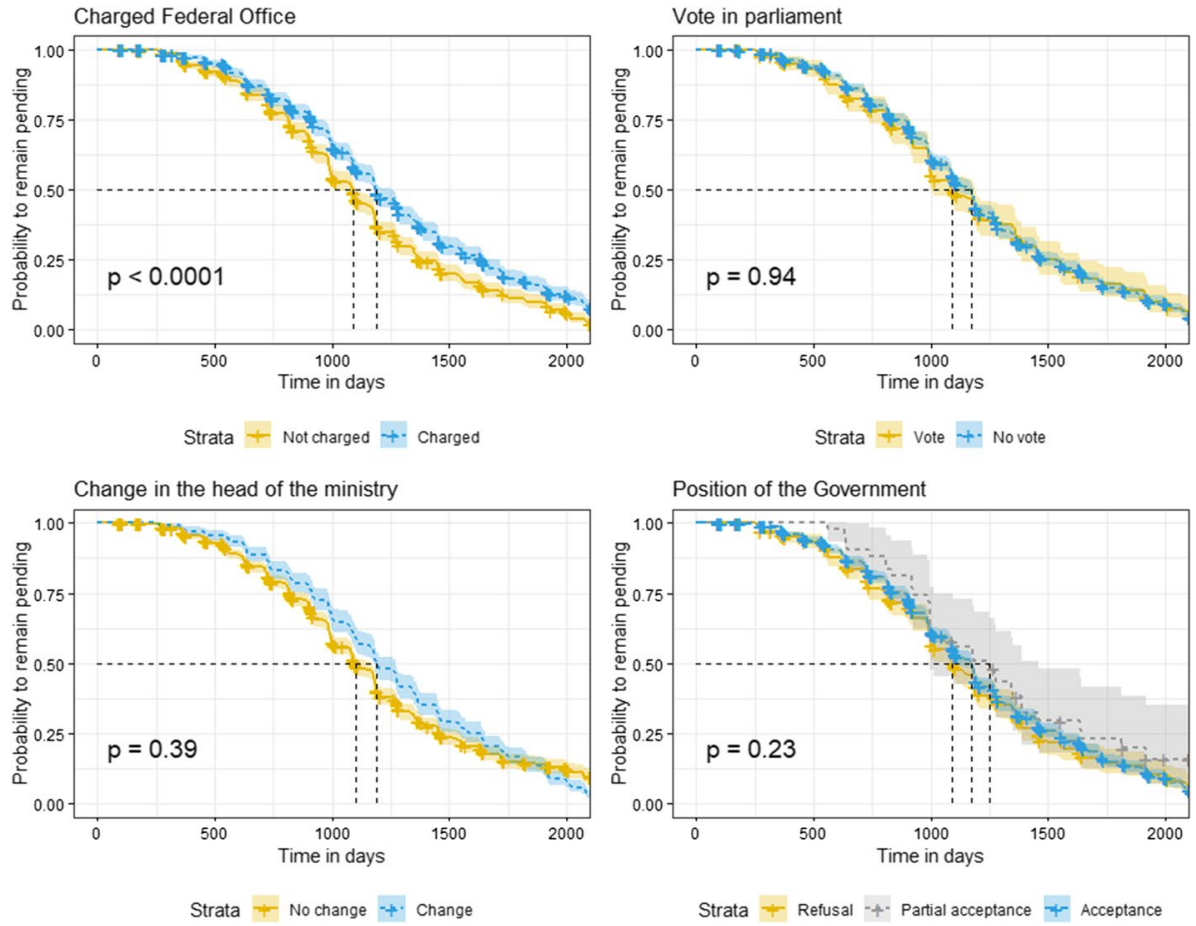

Fig. 2 Survival plots. Source: Prepared by the authors based on the CUBE database. $N=1902$ ( 785 motions and 1117 postulates)

Our hypotheses further suggested that items of business that are supported by the government are implemented faster than items of business that the executive opposes from the start. Yet, as our results show, there is no empirical support for this notion; rather, the opposite seems to be the case: Those parliamentary requests that are accepted by the government are characterized by a longer implementation time. However, the differences are not statistically significant. Nevertheless, the association suggests the interpretation that items supported by the government may be implemented with particular attention and care as the government agrees on the fact that there is a need for action. This strong engagement may require more time.

In contrast, the remaining variables reach statistical significance. First, the model supports our assumption that a high workload of the responsible Federal Offices is associated with implementation lags. While we are not able to empirically test the underlying causal mechanism, we interpret this lag as suggesting that highly busy Federal Offices have limited resources. For this reason, they lack the capacity to implement parliamentary requests within a short time.

Second, this may be related to the finding that implementation time frames vary across different ministries. ${ }^{22}$ Our model specified the Federal Department of the Environment,

\footnotetext{
22 The workload dummy denoting highly burdened Federal Offices and our ministry-based proxy for the complexity of issues are not strongly related. The highly burdened Federal Offices belong to five different ministries. This speaks for the fact that the two variables capture different resource-related aspects that may impede timely implementation.
} 


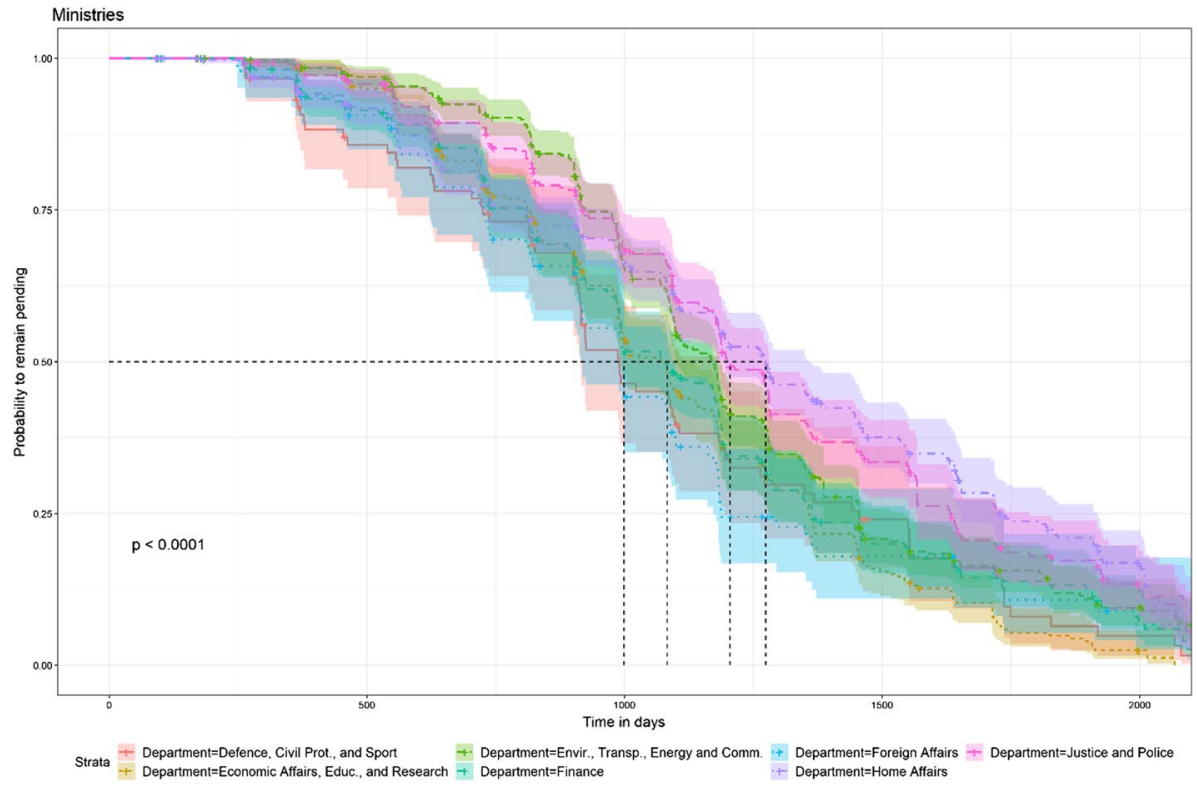

Fig. 3 Differences across departments. Note: Prepared by the authors based on the CUBE database. $N=1902$ (FDFA (Federal Department of Foreign Affairs)=99; FDHA (Federal Department of Home Affairs) $=402$; FDF (Federal Department of Finance) $=285$; FDJP (Federal Department of Justice and Police $=297$; DETEC (Federal Department of the Environment, Transport, Energy and Communications $)=409$; DDPS (Federal Department of Defense, Civil Protection and Sport)=91; and EAER (Federal Department of Economic Affairs, Education and Research) =319)

Transport, Energy and Communication as the reference category. Given almost all other ministries' positive hazard rates, the results indicate that the probability of implementation delays is highest for items of business that are implemented under the responsibility of the Federal Department of Home Affairs. However, while most differences do not reach statistical significance, both the Federal Office of Foreign affairs (as expected) and the Department of Economic Affairs, Education and Research exhibit significantly shorter implementation times than the Environment, Energy and Communication ministry (the reference category). In this vein, the model is also (partly) in line with our hypothesis that the detected variation may be attributed to differences in the ministries' thematic focus.

Third, the regression analysis confirms that changes in the responsible ministry's head delay parliamentary requests' implementation. In accordance with our hypothesis, this can be explained with the fact that such changes imply periods of vocational adjustment. Moreover, in the Swiss consensual multiparty government-and unlike the so-called midnight rule-making practice of outgoing presidents in the USA (O'Connell, 2008; Potter, 2017) it is assumed that members of government who plan to take on a new ministry or to step down in the foreseeable future do not tackle items of business that they cannot successfully conclude in their remaining time in office.

Lastly, regarding our control variables, whether or not another legislative request with a similar or identical context exists does not significantly affect implementation times. Furthermore, the results show that parliamentary requests submitted in a more recent legislative term have a significantly lower hazard rate, i.e. a higher probability of still being 


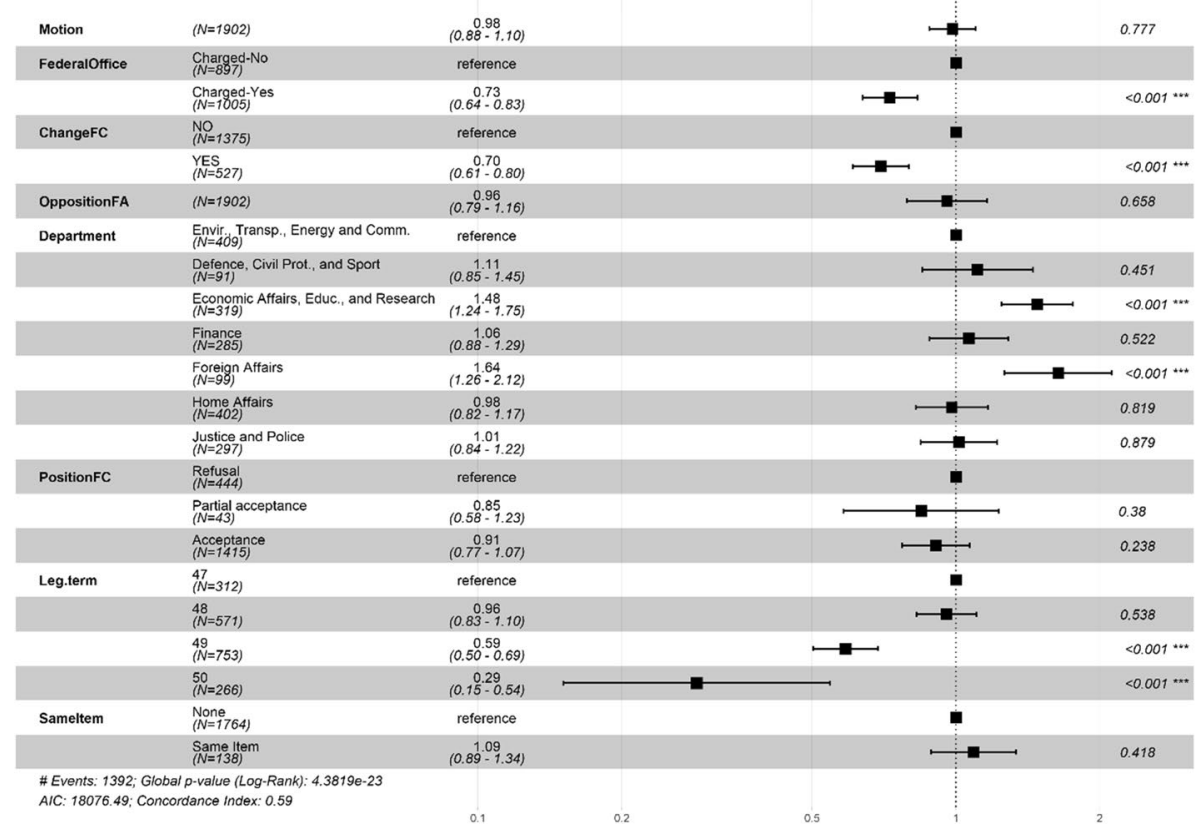

Fig. 4 Survival model. Note: Hazard rates with $95 \%$-confidence intervals. $N=1902$ observations. Observations that fall within the responsibility of the Federal Chancellery and the parliament are excluded due to low number of cases. Outliers (i.e. items of business that were not implemented within 2200 days) were also excluded

pending. ${ }^{23}$ This may be the result of the data's specific time structure. Conversely, there is no indication that varying political dynamics during the different legislation terms affected the implementation time frame of legislative requests.

\section{Conclusions}

With this paper, we seek to contribute to the literature on parliaments' legislative agendasetting power and the associated executive-legislative relations by investigating whether and how the government may influence parliamentary legislative agenda setting. More precisely, we focused on the Swiss case and asked how the time variation in the implementation of parliamentary requests can be explained. We relied on a novel database including a systematic collection of all motions and postulates that have been approved between the parliament's 2003 winter session and its 2018 spring session. The most important findings can be summarized as follows.

First, the Swiss government implements most parliamentary requests within 800 and 1500 days, i.e. within, approximately, two to four years. While there is no strict criterion determining whether this implementation time is appropriate or too long, the considerable ${ }^{23}$ As Fig. $8 \mathrm{c}$ in "Appendix" demonstrates, the use of a metric time variable instead of legislative terms
leads to the same conclusion, while all other findings remain unchanged. 
time variation suggests that factors internal to the implementation process influence the time needed for implementing a parliamentary request.

Second, when investigating the latter, it is obvious that time variation in implementing parliamentary requests is associated with a range of different factors. More precisely, the implementation of parliamentary requests takes significantly longer if the responsible Federal Office is burdened with many requests, if the request is likely to cover a complex or controversial issue, and if the head of the responsible ministry changes during the implementation process. Conversely, we did not find evidence for our assumption about the differences across request types. Likewise, opposition from within the parliament does not seem to be associated with the length of an item's implementation period, nor do we find a statistically consistent relationship between the government's position on a legislative request and the latter's implementation time.

In terms of policy implications, our results largely confirm the findings of existing implementation research-effective implementation is driven by resource-related and structural conditions. In accordance with prior research pointing to the importance of adequate administrative structures and sufficient management resources (Sager, 2007; Simmons, 2002), we conclude that a high workload may lead to delays in the processing and implementation of parliamentary requests. Moreover, Sabatier and Mazmanian (1980) describe a high degree of stability in framework conditions as one of six prerequisites for high implementation success. Our findings imply that changes of the head of a ministry (but also when parliamentary requests move from one ministry to another) disrupt this stability and complicate implementation, as they tie resources up and entail a loss of expertise. It needs to be mentioned that our findings stem from a highly stable political context. For example, there has not been a single change in the party-political composition of the Swiss collegial government between 1959 and 2003, and the same four parties that gained representation in 1960 were still represented in the executive in 2020. Accordingly, the combination of a broad-based multiparty government and strong direct democracy has resulted in the absence of a "classic" parliamentary opposition in Switzerland (Church \& Vatter, 2009). If changes in government and administrative reorganization are important drivers of implementation delays in a context like Switzerland, it seems relevant to more specifically investigate these factors, especially in political systems characterized by lower levels of stability.

A second implication is that a lengthy implementation of parliamentary requests does not primarily result from hampered opportunities or the government's lack of will to implement parliamentary demands. Put differently, there is no support for the idea that the government "shall not" or "does not want to" implement faster. Rather, long implementation periods are mostly related to the fact that the government "cannot" implement faster (the inability argument), i.e. to factors such as highly busy Federal Offices or complex and controversial issues, while delays may be less significantly related to the government taking advantage of its role as a gate keeper. 
Our study is certainly not without limitations. Most important, while we were able to make use of a novel data set, the available data mainly provide information about procedural and structural factors, while almost no information about the specific content of a parliamentary request is available. This makes it impossible to delve deeper into the implementation's quality. A path for future research could be to study the relationship between the time used for implementing parliamentary requests and the extent to which the parliament's will is actually implemented. Moreover, the study focuses exclusively on Switzerland, which exhibits a particular formal setting in terms of the relationship between the executive and the legislative.

Nevertheless, besides the substantial implications discussed above, we argue that our study also provides important insights for policy analysis in general and into the role of governments in implementing legislative requests more specifically. Switzerland still allows us to investigate the case of an independent and active legislature in a non-parliamentary but European multiparty system. Our study thereby contributes to the current "parliamentary decline thesis" in parliamentary systems of government (Kreppel, 2014) and offers a possible answer to the question of what could happen in these systems if the legislature and its members played a more powerful role in initiating legislation.

More conceptually, our analysis demonstrates that focusing on the procedural dimension can provide new empirical and theoretical insights into the executive-legislative relationship. Empirically, our study suggests that previous research may have overestimated the government's agenda-setting power, mainly because structural and resource aspects limit governments' control over the implementation of parliament's requests. Theoretically, we are able to show that the combination of parliamentary research and implementation studies enables us to formulate different mechanisms that may affect the executive-legislative relationship in practice. Specifically, the comparison with bureaucratic rule-making in the USA (Bolton et al., 2016; Potter, 2017) or multilevel governance, e.g. in the European Union (Borghetto \& Franchino, 2010; König \& Luetgert, 2009), demonstrates that different elements of policy making in different political settings can be theoretically and conceptually analysed by relying on very similar mechanisms. Making use of these similarities may be a fruitful path for further research; for example, in efforts to generate more generalized knowledge about the conditions under which "sincere" or "strategic delay" are likely to occur, namely, whether any systematic patterns contingent on the political system or the specific stage of rule-making can be identified.

\section{Appendix}

See Figs. 5, 6, 7 and Table 2. 


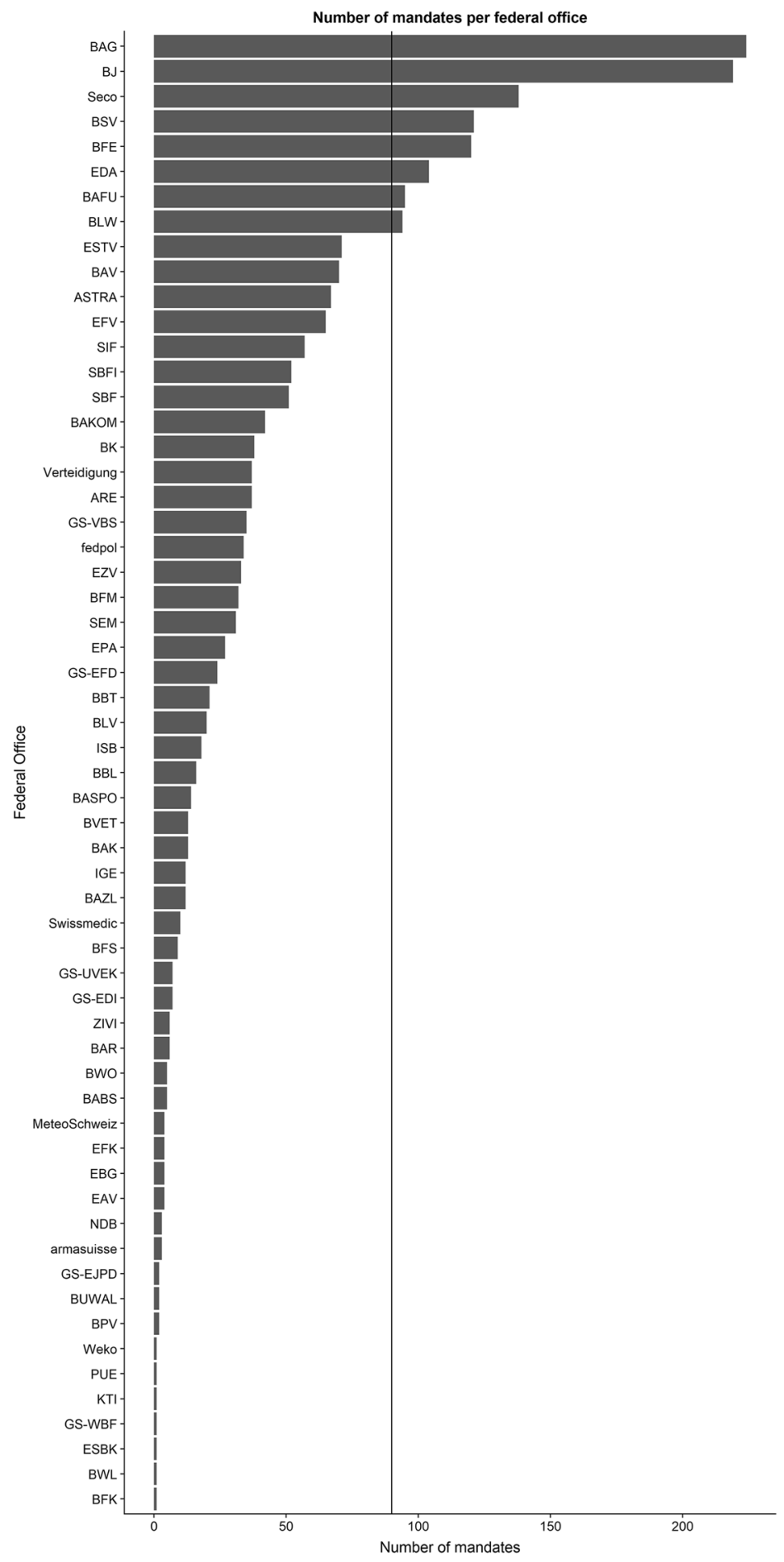

Fig. 5 Number of legislative requests per Federal Office. Note: Prepared by the authors based on the CUBE database. $N=2147$ (922 motions and 1225 postulates) 


\section{Position parliament}

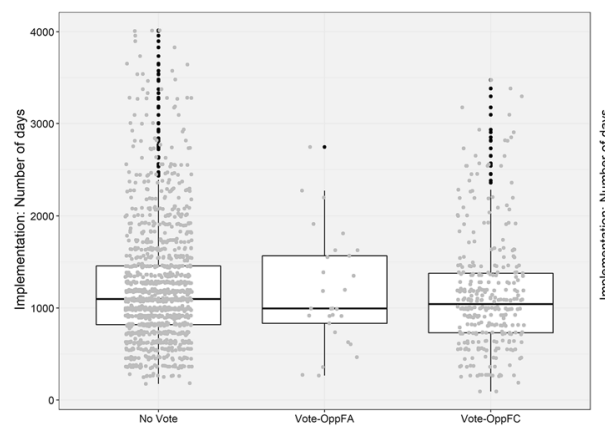

\section{Position Government}

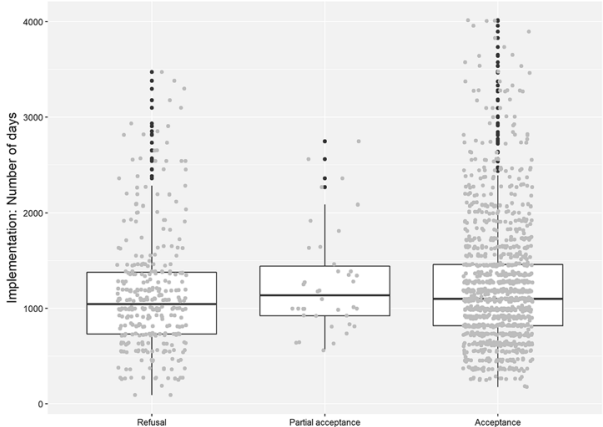

Fig. 6 Descriptive figures. Note: Box plots, based on abandoned parliamentary requests only. Left graph: $N=1564$ (No vote $=1205$, Yes $=359)$; right graph: $N=1562$ (Acceptance $=1194$; Partial acceptance $=38$; Refusal $=330$ ). Source: Prepared by the authors based on the CUBE database

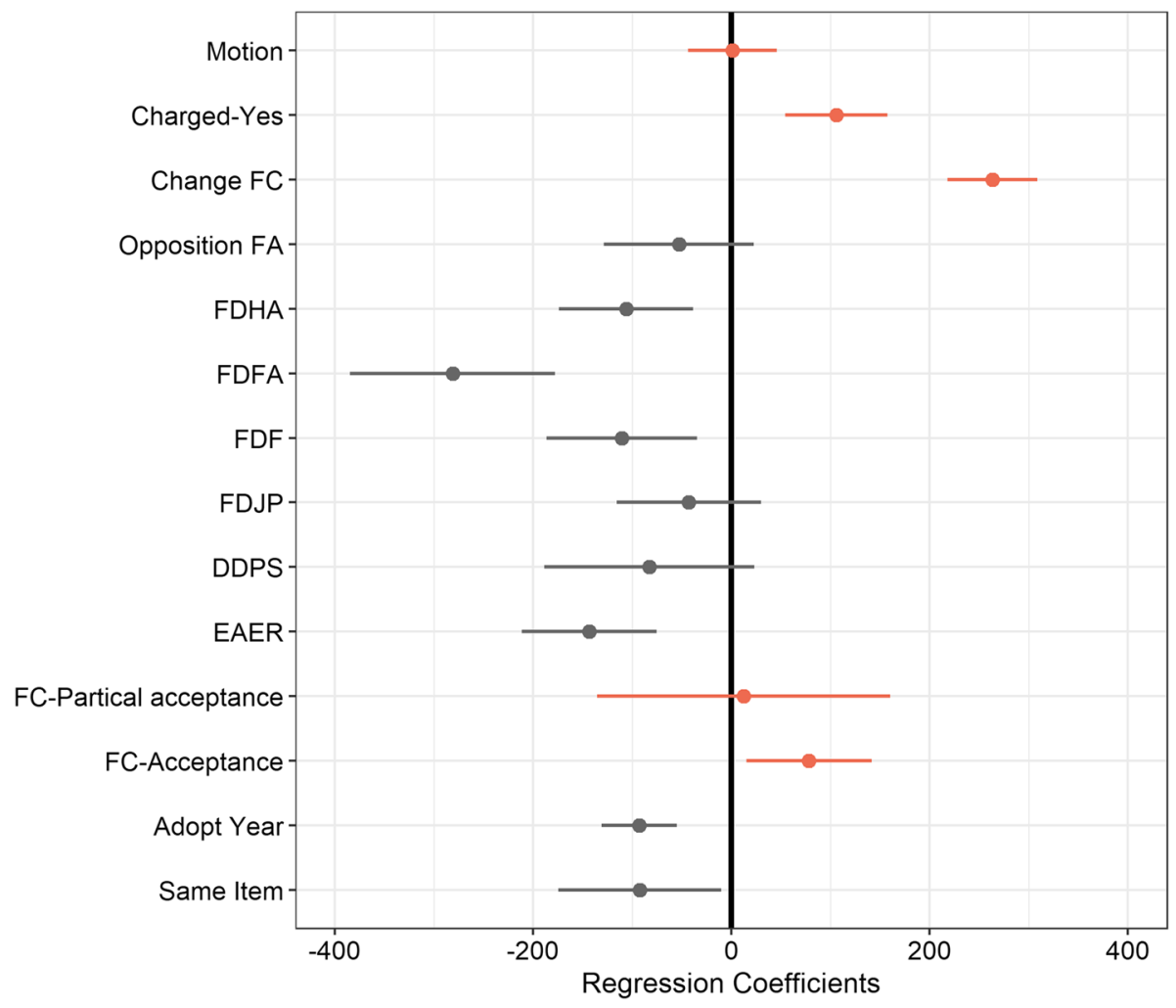

Fig. 7 OLS regression results focusing on abandoned parliamentary requests. Note: Regression estimates with $95 \%$ confidence intervals. $N=1392$ observations. Observations that fall within the responsibility of the Federal Chancellery and the parliament are excluded due to low number of cases. Outliers (i.e. items of business that were not implemented within 2200 days) were also excluded. For illustrative purposes, positive coefficients are in orange and the year of adoption has been divided by 5 
Table 2 Descriptive statistics

Implementation time: all requests

Mean (SD)

$1187.4(742.5)$

Median (Q1, Q3)

$1082(720,1456)$

Min-Max

0-5121

Missing

0

Implementation time: abandoned requests only

Mean (SD)

$1218.0(639.8)$

Median (Q1, Q3)

$1091.5(814,1456)$

Min-Max

Missing (i.e. pending)

92-4015

669

Type of parliamentary request

Motion

$977(43.8 \%)$

Postulate

$1256(56.2 \%)$

Missing

0

Charged federal office

NO

$1032(48.1 \%)$

YES

$1115(51.9 \%)$

Missing

86

Personnel changes FC

NO

$1582(70.8 \%)$

YES

$651(29.2 \%)$

Missing

0

Opposition in federal assembly

Mean (SD)

$0.754(0.353)$

Median (Q1, Q3)

Min - Max

$1.000(0.4031 .000)$

Missing

0.005-1.000

0

Opposition federal council

Refusal

$537(24.1 \%)$

Partial acceptance

$58(2.6 \%)$

Acceptance

$1636(73.3 \%)$

Missing

2

Responsible ministry

BK

$40(1.8 \%)$

FDFA

$108(4.8 \%)$

FDHA

$477(21.4 \%)$

FDF

$340(15.2 \%)$

FDJP

$345(15.5 \%)$

Parliament

$11(0.5 \%)$

DETEC

$470(21.0 \%)$

DDPS

$98(4.4 \%)$

EAER

344 (15.4\%)

Missing

0

Adoption year

Mean (SD)

Median (Q1, Q3) 
Table 2 (continued)

\begin{tabular}{ll}
\hline Min-Max & $2004-2018$ \\
Missing & 0 \\
Same item & \\
None & $2055(92.0 \%)$ \\
Same Item & $178(8.0 \%)$ \\
Missing & 0 \\
Legislative term & \\
47 & $425(19.1 \%)$ \\
48 & $691(30.9 \%)$ \\
49 & $782(35.0 \%)$ \\
50 & $334(15.0 \%)$ \\
Missing & \\
& Overall $(N=2233)$
\end{tabular}

\section{Robustness analyses: additional models}

See Fig. 8. 
(a) Workload as a metric variable

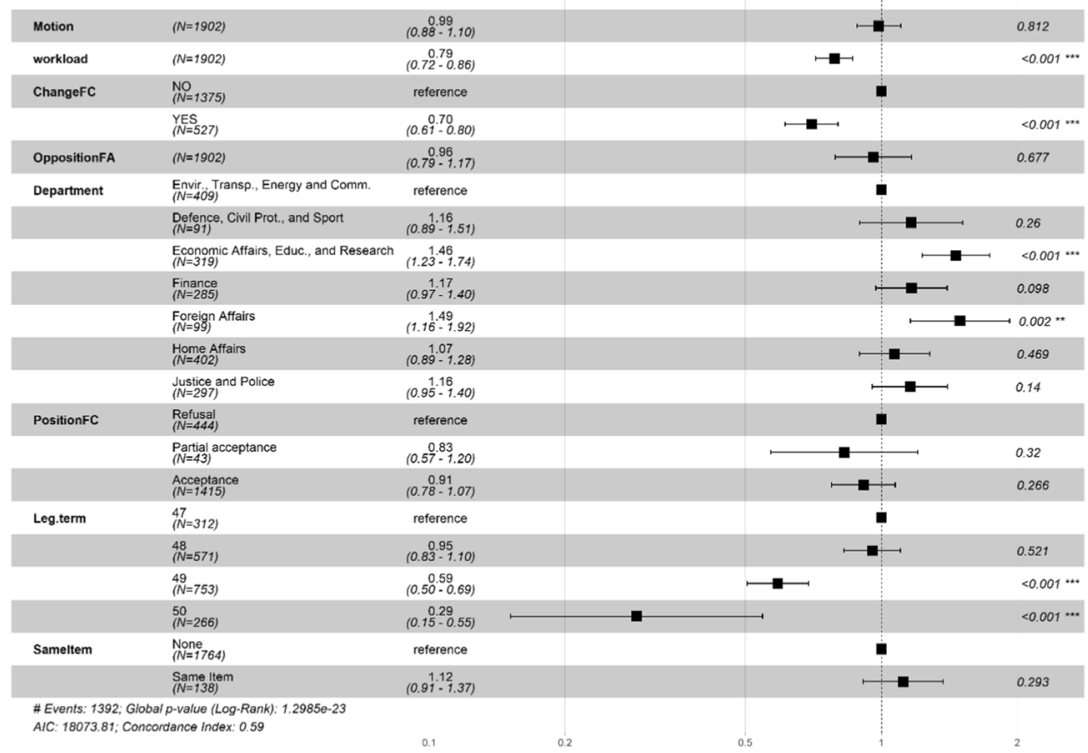

\section{(b) Additional covariates}

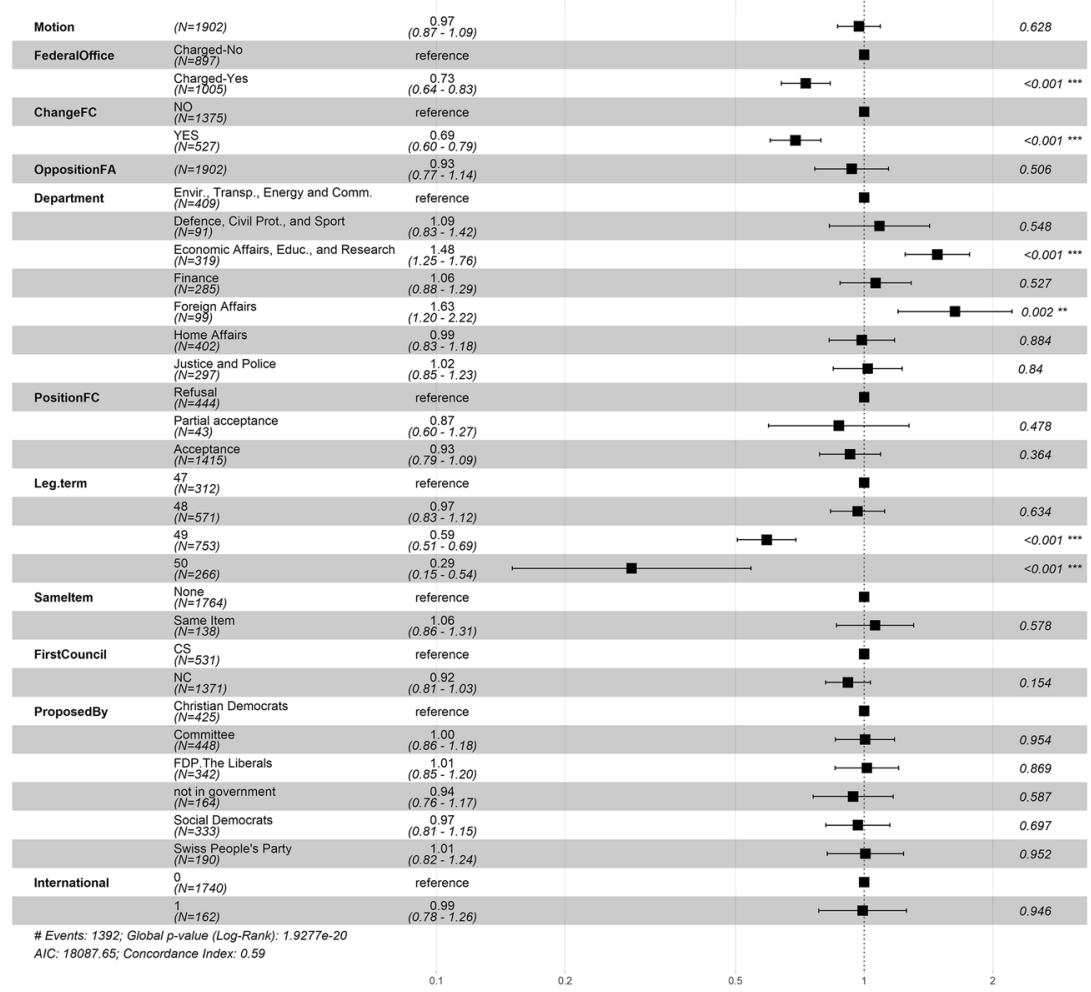




\section{(c) Time as a metric variable}

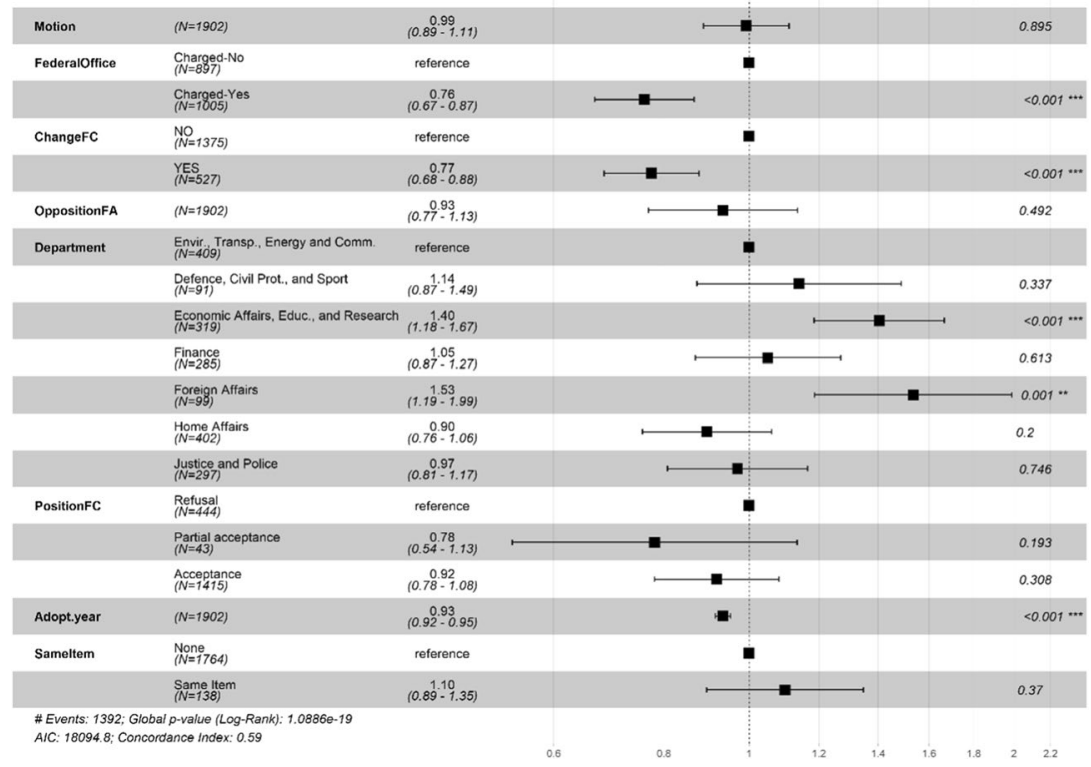

Fig. 8 (continued)

Fig. 8 a Workload as a metric variable. Note: Basic model as presented in Fig. 4 but using a metric specification of a Federal Office's workload instead of a dummy. The workload variable has been divided per 100 (i.e. number of requests/100) to make the coefficient and the interval visible. b Additional covariates. Note: Basic model as presented in Fig. 4 but with additional control variables. First Council: The chamber of parliament that initiated the legislative request. Proposed By: The initiator of a request, namely whether it was proposed by a (multiparty) committee or by a specific party. International: Whether (1) or not (0) a parliamentary request contains a supranational aspect, potentially involving more complexity due to multilevel governance. $\mathbf{c}$ Time as a metric variable. Note: Basic model as presented in Fig. 4 but using a metric specification of time instead of the legislative term

Supplementary Information The online version contains supplementary material available at https://doi. org/10.1007/s11077-021-09432-4.

Funding Open Access funding provided by Universität Bern. Open Access funding provided by Universität Bern. Funding was provided by Parliamentary Control of the Administration (Based on a commissioned study).

Open Access This article is licensed under a Creative Commons Attribution 4.0 International License, which permits use, sharing, adaptation, distribution and reproduction in any medium or format, as long as you give appropriate credit to the original author(s) and the source, provide a link to the Creative Commons licence, and indicate if changes were made. The images or other third party material in this article are included in the article's Creative Commons licence, unless indicated otherwise in a credit line to the material. If material is not included in the article's Creative Commons licence and your intended use is not permitted by statutory regulation or exceeds the permitted use, you will need to obtain permission directly from the copyright holder. To view a copy of this licence, visit http://creativecommons.org/licenses/by/4.0/. 


\section{References}

Bailer, S. (2011). People's voice or information pool? The role of, and reasons for, parliamentary questions in the Swiss Parliament. The Journal of Legislative Studies, 17(3), 302-314.

Bernauer, J., \& Vatter, A. (2019). Power Diffusion and Democracy: Institutions, Deliberation and Outcomes. Cambridge University Press.

Bolton, A., Potter, R. A., \& Thrower, S. (2016). Organizational capacity, regulatory review, and the limits of political control. Journal of Law, Economics, and Organization, 32(2), 242-271.

Borghetto, E., \& Franchino, F. (2010). The role of subnational authorities in the implementation of EU directives. Journal of European Public Policy, 17(6), 759-780.

Borzel, T. A. . (2001). Non-compliance in the European Union: Pathology or statistical artefact? Journal of European Public Policy, 8(5), 803-824.

Box-Steffensmeier, J., \& Jones, B. (1997). Time is of the essence: Event history models in political science. American Journal of Political Science, 41(4), 1414-1461.

Box-Steffensmeier, J., \& Jones, B. (2004). Event history modeling: A guide for social scientists. Cambridge University Press.

Brüschweiler, J., \& Vatter, A. (2018). Viele Vorstösse, wenig Wirkung? Nutzung und Erfolg parlamentarischer Instrumente in der Bundesversammlung. In A. Vatter (Ed.), Das Parlament in der Schweiz. Macht und Ohnmacht der Volksvertretung (pp. 69-99). NZZ Libro.

Chayes, A., \& Handler Chayes, A. (1993). On compliance. International Organization, 47(2), 175-205.

Church, C. H., \& Dardanelli, P. (2005). The Dynamics of confederalism and federalism: Comparing Switzerland and the EU. Regional \& Federal Studies, 15(2), 163-185.

Church, C. H., \& Vatter, A. (2009). Opposition in consensual Switzerland: A short but significant experiment. Government and Opposition, 44(4), 412-437.

Colomer, J. M., \& Negretto, G. L. (2005). Can presidentialism work like parliamentarism? Government and Opposition, 40(1), 60-89.

Döring, H. (2001). Parliamentary agenda control and legislative outcomes in western Europe. Legislative Studies Quarterly, 26(1), 145-165.

Falkner, G., Treib, O., Hartlapp, M., \& Leiber, S. (2005). Complying with Europe? Theory and practice of minimum harmonisation and soft law in the multilevel system. Cambridge University Press.

Fish, S. M. (2006). Stronger legislatures, stronger democracies. Journal of Democracy, 17(1), 5-20.

Flick Witzig, M., \& Bernauer, J. (2018). Aus der Balance? Das Verhältnis von Parlament und Regierung im internationalen Vergleich. In A. Vatter (Ed.), Das Parlament in der Schweiz. Macht und Ohnmacht der Volksvertretung (pp. 425-454). NZZ Libro.

Goetschel, L. (2014). Aussenpolitik. In P. Knoepfel, Y. Papadopoulos, P. Sciarini, A. Vatter, \& S. Häusermann (Eds.), Handbuch der Schweizer Politik (pp. 623-643). NZZ Libro.

Golub, J. (2007). Survival Analysis. In J. Box-Steffensmeier, H. Brady, \& D. Collier (Eds.), Handbook of political methodology (pp. 530-546). Oxford University Press.

Graf, M. (2014). Abschnitt: Motion. In M. Graf, C. Theler, \& M. von Wyss (Eds.), Parlamentsrecht und Parlamentspraxis der Schweizerischen Bundesversammlung. Kommentar zum Parlamentsgesetz (ParlG) (Vol. 13). Helbing \& Lichtenhahn.

Graf, M. (1991). Motion und parlamentarische Initiative: Untersuchungen zu ihrer Handhabung und politischen Funktion. In In. Parlamentsdienste (Ed.), Das Parlament-Oberste Gewalt des Bundes? Festschrift der Bundesversammlung zur 700-Jahr-Feier der Eidgenossenschaft (pp. 203-221). Haupt.

Graf, M., Theler, C., \& von Wyss, M. (2014). Parlamentsrecht und Parlamentspraxis der Schweizerischen Bundesversammlung, Kommentar zum Parlamentsgesetz (ParlG). (Vol. 13). Helbing \& Lichtenhahn.

Jaquet, J. M., Sciarini, P., \& Varone, F. (2019). Policy-agenda-setting: Regierung als Hauptinitiator von Entscheidungsprozessen? In A. Ritz, T. Haldemann, \& F. Sager (Eds.), Blackbox Exekutive. Regierungslehre in der Schweiz (pp. 213-233). NZZ Libro.

Jenkins, J. A., \& Monroe, N. W. (2016). On measuring legislative agenda-setting power. American Journal of Political Science, 60(1), 158-174.

King, A., \& Crewe, I. (2013). The blunders of our governments. Oneworld.

Klöti, U. (2007). The government. In U. Klöti, P. Knoepfel, H. Kriesi, W. Linder, Y. Papadopoulos, \& P. Sciarini (Eds.), Handbook of Swiss politics (2nd ed., pp. 145-169). NZZ Libro.

Knill, C., \& Tosun, J. (2012). Public policy: A new introduction. Palgrave.

Kreppel, A. (2014). Typologies and classifications. In S. Martin, T. Saalfeld, \& K. Strom (Eds.), The Oxford handbook of legislative studies (pp. 82-101). Oxford University Press.

König, T., \& Luetgert, B. (2009). Troubles with transposition? Explaining trends in member-state notification and the delayed transposition of EU directives. British Journal of Political Science, 39(1), $163-194$. 
Lijphart, A. (2012). Patterns of democracy: Government forms and performance in thirty-six countries (2nd ed.). Yale University Press.

Linder, W. (2007). Political culture. In U. Klöti, P. Knoepfel, H. Kriesi, W. Linder, Y. Papadopoulos, \& P. Sciarini (Eds.), Handbook of Swiss politics (2nd ed., pp. 15-34). NZZ Libro.

Linder, W., \& Mueller, S. (2021). Swiss democracy: Possible solutions to conflict in multicultural societies (4th ed.). Palgrave Macmillan.

Lüthi, R. (2007). The parliament. In U. Klöti, P. Knoepfel, H. Kriesi, W. Linder, Y. Papadopoulos, \& P. Sciarini (Eds.), Handbook of Swiss politics (2nd ed., pp. 121-144). NZZ Libro.

Martin, L. W., \& Vanberg, G. (2005). Coalition policymaking and legislative review. The American Political Science Review, 99(1), 93-106.

Mattson, I. (1995). Private members' initiatives and amendments. In H. Döring (Ed.), Parliaments and majority rule in Western Europe (pp. 448-487). Campus Verlag.

O'Connell, A. J. (2008). Political cycles of rulemaking: An empirical portrait of the modern administrative state. Virgina Law Review, 94(4), 889-986.

Parliamentary Control of the Administration (2018). CUBE Dataset. (Unpublished).

Political Institutions Committee (PIC-N). (2007). Parlamentarische Initiative. Verbindliche Wirkung der Motion. Bericht der Staatspolitischen Kommission des Nationalrats.

Potter, R. A. (2017). Slow-rolling, fast-tracking, and the pace of bureaucratic decisions in rulemaking. Journal of Politics, 79(3), 841-855.

Rasch, B. E., \& Tsebelis, G. (Eds.). (2011). The role of governments in legislative agenda setting. Routledge.

Rokkan, S. (1970). Foreword. In J. Steiner (Ed.), Gewaltlose Politik und kulturelle Vielfalt (pp. 5-6). Bern and Stuttgart.

Russell, M., \& Cowley, P. (2016). The policy power of the westminster parliament: The "parliamentary state" and the empirical evidence. Governance, 29(1), 121-137.

Sabatier, P., \& Mazmanian, D. (1980). Implementation of public policy: A framework of analysis. Policy Studies Journal, 8(4), 538-560.

Sager, F. (2007). Making transport policy work: Polity, policy, politics and systematic review. Policy \& Politics, 35(2), 269-288.

Schwarz, D., Bächtiger, A., \& Lutz, G. (2011). Switzerland. Agenda setting power of the government in a separation-of-powers framework. In B. E. Rasch \& G. Tsebelis (Eds.), The role of governments in legislative agenda setting (pp. 127-144). Routledge.

Sciarini, P., Fischer, M., Gavac, R., \& Varone, F. (2021). The influence of co-sponsorship on MPs' agendasetting success. West European Politics, 44(2), 327-353.

Sciarini, P. (2007). The decision-making process. In U. Klöti, P. Knoepfel, H. Kriesi, W. Linder, Y. Papadopoulos, \& P. Sciarini (Eds.), Handbook of Swiss politics (2nd ed., pp. 465-499). NZZ Libro.

Shugart, M. S., \& Carey, J. M. (1992). Presidents and assemblies: Constitutional design and electoral dynamics. Cambridge University Press.

Siaroff, A. (2003). Varieties of parliamentarianism in the advanced industrial democracies. International Political Science Review, 24(4), 445-464.

Simmons, B. A. (2002). Capacity, commitment, and compliance: International institutions and territorial disputes. The Journal of Conflict Resolution, 46(6), 829-856.

Strøm, K., Müller, W. C., \& Markham Smith, D. (2010). Parliamentary control of coalition governments. Annual Review of Political Science, 13, 517-535.

Swiss Parliament (2019). Lexicon of parliamentary terms. https://www.parlament.ch. Accessed: 18 February 2019.

Swiss Federal Chancellery (2019). The Swiss Confederation—A brief guide. https://www.bk.admin.ch/bk/en/ home/dokumentation/the-swiss-confederation-a-brief-guide.html. Accessed: 15 March 2019.

Tsebelis, G. (1995). Decision making in political systems: Veto players in presidentialism, parliamentarism, multicameralism and multipartyism. British Journal of Political Science, 25(3), 289-325.

Tsebelis, G. (2009). Agenda setting and executive dominance in politics. In Ganghof, S., Hönnige, C., \& Stecker, C., (Eds.), Parlamente, Agendasetzung und Vetospieler: Festschrift für Herbert Döring (pp. 13-24). VS Verlag Sozialwissenschaften, Wiesbaden.

Vatter, A. (2018). Das Parlament in der Schweiz Macht und Ohnmacht der Volksvertretung. NZZ Libro.

Vatter, A. (2020). Das politische System der Schweiz (4th ed.). Auflage.

Vatter, A., Freiburghaus, R., \& Arens, A. (2020). Coming a long way: Switzerland's transformation from a majoritarian to a consensus democracy (1848-2018). Democratization, 27(6), 970-989.

Vatter, A., \& Wirz, R. (2015). Der Einfluss der Bundesversammlung auf die Gesetzgebung unter besonderer Berücksichtigung der Parlamentarischen Initiative. Studienbericht erstellt mit finanzieller Unterstützung durch die Parlamentsdienste des Bundes. 
West, W. F., \& Raso, C. (2013). Who shapes the rulemaking agenda? Implications for bureaucratic responsiveness and bureaucratic control. Journal of Public Administration Research and Theory, 23(3), 495-519.

Publisher's Note Springer Nature remains neutral with regard to jurisdictional claims in published maps and institutional affiliations. 